\title{
PENYELENGGARAAN SIARAN TELEVISI UNTUK PENDIDIKAN DI INDONESIA: SEBUAH KAJIAN HISTORIS
}

Oleh: Sudirman Siahaan ${ }^{*}$ dan Rahmi Rivalina*)

\section{Abstrak}

Pada awalnya, gagasan untuk menyelenggarakan siaran televisi yang khusus berkiprah di bidang pendidikan/pembelajaran dimulai dari kerjasama Pusat Teknologi Komunikasi Pendidikan dan Kebudayaan (Pustekkom) dengan UNICEF/UNESCO memproduksi program televisi pendidikan/ pembelajaran untuk ditayangkan melalui stasiun televisi yang ada. Program yang diproduksi adalah mengenai pengembangan watak anak-anak. Keberhasilan yang dicapai dilanjutkan dengan pengembangan film serial Aku Cinta Indonesia $(\mathrm{ACl})$ yang ditayangkan setiap hari Minggu oleh stasiun TVRI Jakarta. Melalui kerjasama dengan pemerintah Australia, Belanda, dan Kanada, gagasan untuk menyelenggarakan siaran televisi pendidikan/pembelajaran secara perlahanlahan mulai mengarah jelas. Sumber daya dipersiapkan dan demikian juga dengan programprogram pendidikan/pembelajaran yang akan ditayangkan. Kerjasama terhenti namun perjuangan untuk penyelenggaraan siaran televisi pendidikan/pembelajaran tiada pernah berhenti. Perjuangan berikutnya adalah menjalin kerjasama dengan perusahaan swasta, PT. Cipta Televisi Pendidikan Indonesia (grup PT. Lamtoro Gung Persada) yang pada akhirnya berhasil mendirikan stasiun Televisi Pendidikan Indonesia (Stasiun TPI). Melalui stasiun TPI ditayangkanlah programprogram pendidikan/pembelajaran yang dikenal dengan Siaran Televisi Pendidikan Sekolah (STVPS). Kerjasama yang disepakati berlangsung selama 15 tahun ternyata hanya dapat bertahap selama 5 tahun. Pada tahun 1997, PT. Medicitra Indostar mendedikasikan satu saluran khusus pada satelit Cakrawarta-1 untuk penyelenggaraan siaran televisi pendidikan melalui satelit siaran langsung (SSL). Kegiatan ini juga ternyata tidak berlangsung lama. Pada tanggal 12 Oktober 2004, perjuangan untuk menyelenggarakan siaran televisi yang secara khusus berkiprah di bidang pendidikan/pembelajaran menuai hasil dengan dicanangkannya Siaran Televisi Edukasi (TVE) oleh Menteri Pendidikan Abdul Malik Fadjar. Siaran TVE yang diawali dengan mengudara selama 2 jam tayang setiap harinya, kini meningkat menjadi 24 jam setiap harinya sejak tahun 2009.

Kata kunci: Film Serial Aku Cinta Indonesia, Siaran Televisi Pendidikan Sekolah, Siaran Televisi Edukasi, model-model pemanfaatan siaran Televisi Edukasi

*) Drs. Sudirman Siahaan, M.Pd., adalah tenaga fungsional peneliti pada Pusat Teknologi Informasi dan Komunikasi Pendidikan (Pustekkom)-Departemen Pendidikan Nasional.

**) Rahmi Rivalina, M.Hum., adalah tenaga fungsional peneliti pada Pusat Teknologi Informasi dan Komunikasi Pendidikan (Pustekkom)-Departemen Pendidikan Nasional. 


\section{A. PENDAHULUAN}

Secara umum, siaran televisi lebih dikenal masyarakat sebagai media hiburan. Pada kenyataannya, siaran televisi memang merupakan salah satu media hiburan yang paling banyak diminati masyarakat pada era sebelum mem-booming-nya internet di Indonesia. Siaran televisi tidak mengenal batas usia pemirsa. Pengelola siaran televisi memahami benar potensi yang dimiliki siaran televisi sehingga program-program yang ditayangkan juga disesuaikan dengan berbagai segmen masyarakat. Masyarakat dikondisikan sedemikian rupa agar mereka merasa betah atau penasaran untuk menonton seluruh atau sebagian besar program yang ditayangkan stasiun TV tertentu.

Dengan harga antena parabola yang semakin relatif terjangkau, maka semakin banyak masyarakat luas yang dapat menikmati berbagai acara yang ditayangkan oleh stasiun-stasiun TV swasta dan TV kabel secara terusmenerus (nonstop). Demikian juga halnya dengan iklan atau promosi berbagai produk yang dikemas secara menarik dan ditayangkan secara terus-menerus dapat mempengaruhi pola pikir, sikap atau perilaku pemirsa/konsumen. Di samping dampak positif, banyak juga ditemukan dampak negatif yang diakibatkan oleh kehadiran siaran televisi.

Acara televisi untuk pendidikan, khususnya yang berkaitan dengan kepentingan pengembangan anak-anak usia sekolah tampaknya masih belum banyak mendapat perhatian pengelola siaran TV. Pada tahun 1982/1983, Departemen Pendidikan dan Kebudayaan melalui Pusat Teknologi Komunikasi Pendidikan dan Kebudayaan (Pustekkom) bekerjasama dengan UNICEF/UNESCO mengembangkan film pendidikan yang bertemakan pengembangan watak anak-anak Sekolah Dasar (SD). Program ini ditayangkan oleh stasiun Televisi Republik Indonesia (TVRI) (Wirjomartono, 1994).
Pengalaman lainnya adalah pengembangan berbagai jenis program media audio, radio, video, siaran televisi, film, film dokumenter, slide suara, dan transparansi, baik yang ditujukan kepada peserta didik pendidikan dasar, menengah, pendidikan tinggi, dan pendidikan luar sekolah. Pengalaman ini dilanjutkan dengan merancang dan mengembangkan film serial pendidikan yang berfokus pada pengembangan kepribadian anak-anak usia sekolah dasar dan menengah, pendidikan sejarah perjuangan bangsa, dan profil kehidupan profesional guru.

Film serial pendidikan tersebut di atas diberi nama Film Serial Aku Cinta Indonesia $(\mathrm{ACl})$ yang ditayangkan setiap hari Minggu oleh stasiun Televisi Republik Indonesia (TVRI). Pada awalnya, direncanakan untuk mengembangkan dan menayangkan 4 jilid film serial pendidikan. Setiap jilid film serial $\mathrm{ACl}$ ini terdiri atas 52 episode. Dengan demikian, penayangan film serial $\mathrm{ACI}$ direncanakan berlangsung selama 4 (empat) tahun berturut-turut. Namun dalam pelaksanaannya, hanya 3 jilid dari film serial $\mathrm{ACl}$ ini yang sempat ditayangkan stasiun TVRI secara berurutan selama 3 (tiga) tahun.

Ketiga jilid film serial $\mathrm{ACl}$ yang telah diproduksi dan ditayangkan adalah (1) $\mathrm{ACl}$ Jilid-1 tentang pengembangan kepribadian anak-anak usia Sekolah Menengah Pertama (SMP), (2) ACI Jilid2 tentang pendidikan sejarah perjuangan bangsa (PSPB), dan (3) ACI Jilid-3 mengenai pengembangan kepribadian anak-anak usia Sekolah Menengah Atas (SMA). Sedangkan film serial ACI Jilid-4 (tentang profil kehidupan profesional guru), sekalipun pada awalnya sudah dimulai memproduksi beberapa episode dari target 52 episode untuk setahun siaran, tetapi kegiatan produksi terpaksa dihentikan karena berbagai alasan. Rentetannya adalah bahwa beberapa episode film serial $\mathrm{ACl}-4$ yang telah selesai diproduksi, tidak dapat ditayangkan. 
Gagasan Pustekkom-Depdiknas untuk mempunyai stasiun siaran televisi tersendiri yang secara khusus hanya menayangkan program-program pendidikan dan pembelajaran terus diperjuangkan agar dapat diwujudkan menjadi sebuah kenyataan. Dengan modal dasar yang telah dimiliki, baik yang berupa pengalaman, potensi sumber daya manusia, maupun fasilitas, Pustekkom-Depdiknas merintis penyelenggaraan siaran televisi yang secara khusus berkiprah di bidang pendidikan/ pembelajaran. Dalam kaitan ini, Departemen Pendidikan dan Kebudayaan melalui Pustekkom menjalin kerjasama dengan pemerintah Belanda, Australia, dan Kanada dalam mempersiapkan pendirian dan pengelolaan penyelenggaraan stasiun siaran televisi untuk kepentingan pendidikan.

\section{B. KAJIAN LITERATUR}

\section{Pengalaman dari Keberhasilan Siaran Televisi Pendidikan/ Pembelajaran}

Pemerintah China menurut Oos M. Anwas adalah salah satu negara yang sangat serius memanfaatkan siaran televisi, tidak hanya untuk pendidikan formal persekolahan tetapi juga untuk pendidikan masyarakat. Sebagai contoh adalah Central Agricultural Broadcasting and Television School (CABTS) yang berada di bawah naungan Departemen Pemberdayaan Petani menjalin kerjasama dengan Center of China Television (Center of China Television, CCTV-7). Program-program pemberdayaan petani ini disiarkan melalui Channel 7 Center of China Television. Lembaga ini mengembangkan program-program pendidikan yang secara khusus ditujukan untuk kepentingan pemberdayaan para petani perdesaan yang tersebar di seluruh wilayah China (Anwas, 2009).
Sedangkan untuk pendidikan formal persekolahan, khususnya pendidikan tinggi, dikemukakan Oos M. Anwas bahwa ada China Central Radio and TV (CCRTVU). Sasarannya adalah para lulusan Sekolah Menengah yang berada di daerah perdesaan dan terpencil termasuk daerah minoritas dengan tujuan untuk menyediakan kesempatan mengikuti pendidikan tinggi bagi penduduk di daerah tertinggal dan belum berkembang. Materi pelajaran disampaikan melalui berbagai media, sepertisiaran radio, siaran televisi, kaset audio/VCD, internet, dan media cetak. Dalam operasionalisasinya, lembaga ini bekerjasama dengan China Education TV, stasiun TV local/TV Universitas (Anwas, 2009).

Di Amerika Serikat, penyelenggaraan siaran TV secara aktif dan terpadu dalam kegiatan pembelajaran di kelas untuk yang pertama sekali dilakukan pada tahun 1950-an. Program siaran TV untuk pendidikan ini diperlakukan sebagai "master teacher" yang diharapkan pada waktu itu berfungsi sebagai pengganti guru kelas untuk mata pelajaran tertentu. Kemudian, pada tahun 1970-an, program siaran TV untuk pendidikan berfungsi sebagai program pengayaan terhadap materi pembelajaran yang telah diajarkan guru kepada para siswa di sekolah. Sedangkan di Jepang, pemanfaatan siaran TV pendidikan memperlihatkan keadaan yang menarik yaitu bahwa sekitar 98\% Sekolah Dasar (SD) yang ada di Jepang pada tahun 1988 telah memanfaatkan siaran TV Pendidikan Sekolah (Dewabrata, 1994).

Korea Selatan menyelenggarakan siaran TV pendidikan untuk sekolah dimulai pada tahun 1960-an. Siaran TV pendidikan di Korea Selatan ini kemudian berkembang menjadi sebuah saluran khusus untuk pendidikan. Komitmen pemerintah Korea Selatan yang tinggi turut mempercepat perkembangan siaran TV pendidikan yang ditandai dengan didirikannya sebuah lembaga tersendiri untuk menangani sistem siaran 
pendidikan (educational broadcasting system). Porsi siaran TV untuk pendidikan terus meningkat sampai pada tahun 1990-an di mana Korea Selatan telah menyelenggarakan siaran TV untuk pendidikan sebanyak 7 jam lebih setiap hari kecuali pada hari Minggu. Sedangkan pada hari Minggu, jumlah jam siaran TV untuk pendidikan jauh lebih banyak lagi, yaitu sekitar 17 jam (Wirjomartono, 1994).

Sedangkan India, program siaran televisi pendidikannya baru dimulai pada tanggal 24 Oktober 1961. Pada tahap pertama, program siaran TV pendidikan yang ditayangkan ditujukan kepada para siswa SMP dan Sekolah Menengah. Program siaran TV untuk pendidikan ini diproduksi dan ditayangkan oleh stasiun TV yang terdapat Delhi, Bombay, Madras, dan Srinagar. Tujuan utama dari program ini adalah untuk membantu para siswa di bidang sains dan sekaligus juga untuk meningkatkan mutu pembelajaran sains, di samping untuk mengatasi keterbatasan tenaga guru yang bermutu.

Pada awalnya, Norwegia berencana untuk mendirikan suatu organisasi yang mengelola satu saluran khusus di bidang TV pendidikan (cable television). Ternyata setelah dilaksanakan dan dikaji, hasilnya justru tidak seperti yang diharapkan. Oleh karena itu, Norwegia memutuskan untuk beralih pada pemanfaatan stasiun TV lokal dalam menayangkan programprogram pendidikannya. Ternyata model pemanfaatan stasiun TV lokal ini juga dinilai tidak berhasil. Sebagai konsekuensinya, Norwegia kembali mengupayakan pemanfaatan TV melalui saluran satelit siaran langsung.

Penyelenggaraan siaran televisi untuk kepentingan pendidikan/pembelajaran menarik perhatian para ahli untuk menelitinya. Berikut ini diuraikan hasilhasil penelitian yang dilakukan beberapa ahli mengenai program siaran televisi pendidikan/pembelajaran, yaitu:

a. Program "sesame street" merupakan program siaran televisi yang keberhasilannya didasarkan pada fakta bahwa belajar adalah (dan dapat menjadi) menyenangkan. Medium siaran televisi yang sedemikian jauh memang bersifat menghibur (entertaining) tetapi sekaligus juga dapat digunakan untuk membantu lebih memahami kegiatan belajar dan mengajar serta lebih jauh lagi mengenai aktivitas berpikir. Tujuan pengembangan dan penayangan "sesame street" adalah untuk mempromosikan keterampilan kesiapan membaca, konsep dan pengembangan kosakata, dan prilaku kesadaran sosial, seperti: kerjasama, kesediaan berbagi, sikap menghargai perbedaan budaya atau etnis.

Keberhasilan program "sesame street" telah menggugah sekitar 140 negara di dunia (termasuk Indonesia) untuk menyiarkannya melalui sekitar 300 stasiun siaran publik. Anak-anak yang menjadi sasaran dari program "sesame street" dapat dengan cepat belajar alphabet, angka, konsep, dan berbagai hubungan melalui pengulangan. Berdasarkan tujuannya, "sesame street" menayangkan materi siaran yang menggugah anak-anak untuk belajar tentang (1) konsep, (2) keterampilan praktis, dan (3) kesadaran sosial (Siahaan, dkk., 2006).

b. Eksperimentasi pemanfaatan siaran televisi untuk (1) pelajaran geometri bagi peserta didik Kelas $X$ Sekolah Menengah dan (2) pelajaran membaca bagi peserta didik kelas IV dan VI SD. Eksperimen ini dilengkapi juga dengan fasilitas saluran khusus yang dapat digunakan peserta didik untuk melakukan tanya jawab dengan guru (nara sumber) apabila diperlukan. Setelah eksperimen berlangsung selama 10 bulan, peserta didik mengikuti tes penguasaan materi pelajaran. Hasilnya menunjukkan bahwa peserta didik yang mengikuti eksperimen memperlihatkan prestasi belajar yang lebih tinggi dibandingkan dengan hasil tes peserta didik yang 
belajar pada kelas-kelas konvensional.

c. Eksperimentasi pemanfaatan siaran televisi untuk pelajaran Bahasa Inggris dan IImu Pengetahuan Alam (IPA) bagi peserta didik sekolah menengah. Kegiatan eksperimentasi penyelenggaraan kegiatan pembelajaran melalui media televisi berlangsung selama satu semester. Setelah berjalan selama satu semester, peserta didik mengikuti tes yang hasilnya menunjukkan bahwa terdapat kenaikan kemampuan berbahasa Inggris sebanyak 25\%. Sedangkan untuk pelajaran IPA, terdapat kenaikan prestasi belajar peserta didik rata-rata $60 \%$.

d. Eksperimentasi pemanfaatan siaran televisi untuk mata pelajaran matematika yang ditujukan kepada 32 orang guru. Para guru ini dibagi ke dalam dua kelompok, yaitu (1) kelompok eksperimen dan (2) kelompok kontrol. Kelompok eksperimen diminta untuk selalu menonton tayangan program siaran televisi yang berisikan pengajaran Matematika. Sedangkan kelompok kontrol tidak mengikuti tayangan program siaran televisi. Hasil penelitian menunjukkan adanya kenaikan hasil belajar Matematika yang signifikan pada kelompok eksperimen. Di samping itu, mereka juga mengalami kenaikan achievement pada dua dari delapan tes prestasi mengajar.

\section{Pengembangan Siaran Televisi Pendidikan Sekolah dan Penayangannya}

Pemerintah Indonesia melalui Departemen Pendidikan Nasional menjalin kerjasama dengan pemerintah Australia, Belanda, dan Kanada dalam rangka persiapan penyelenggaraan siaran televisi yang didedikasikan sepenuhnya untuk kepentingan pendidikan. Beberapa kesepakatan telah dicapai dan proposal yang akan dijadikan sebagai landasan pelaksanaan kegiatan kerjasama telah dibahas dan disetujui bersama. Dengan pemerintah Australia, program yang disepakati adalah pengembangan pelajaran bahasa Inggris secara terintegrasi untuk peserta didik Sekolah Menengah Pertama Terbuka (SMP Terbuka) dan studi banding ke Australia tentang pemanfaatan siaran televisi melalui satelit (satellite-based television).

Kerjasama dengan pemerintah Belanda adalah yang berkaitan dengan (a) pengembangan program televisi dan multimedia untuk pendidikan dan (b) pengembangan sumber daya manusia di bidang pengembangan program televisi dan multimedia untuk pendidikan. Sejumlah prototipa program pembelajaran telah dikembangkan dan sejumlah staf dari berbagai lembaga yang relevan untuk penyelenggaraan siaran televisi pendidikan/pembelajaran di Indonesia telah dilatih di Television Academy (TELEAC) dan di Radio Netherland Training Center (RNTC) di Belanda. Sedangkan kerjasama dengan pemerintah Kanada adalah di bidang studi banding tentang pemanfaatan siaran radio dan televisi untuk kepentingan pendidikan/pembelajaran pada jenjang pendidikan tinggi.

Berbagai upaya yang mengarah pada pendirian dan penyelenggaraan stasiun siaran televisi yang telah dilaksanakan melalui kerjasama dengan pemerintah Australia, Belanda, dan Kanada terpaksa tidak dapat dilanjutkan (dihentikan) karena berbagai pertimbangan. Sekalipun demikian, gagasan untuk pendirian siaran televisi yang secara khusus berkiprah di bidang pendidikan/ pembelajaran tidak pernah berhenti. Memperhatikan terhentinya upaya penyelenggaraan siaran televisi khusus di bidang pendidikan/pembelajaran, pihak swasta yang berminat di bidang pengembangan kualitas sumber daya manusia melalui penyelenggaraan siaran televisi, mengajak Departemen Pendidikan Nasional untuk bekerjasama melanjutkan gagasan yang terhenti. 
Terhentinya kerjasama persiapan penelenggaraan stasiun siaran televisi dengan pemerintah Australia, Belanda, dan Kanada di satu sisi, dan terbukanya peluang untuk melanjutkan rencana penyelenggaraan stasiun siaran televisi dengan pihak swasta dalam negeri, maka Departemen Pendidikan Nasional menjalin kerjasama dengan lembaga swasta yang berkomitmen untuk bersama-sama menyelenggarakan siaran televisi yang khusus berkiprah di bidang pendidikan. Pihak swasta yang dimaksudkan adalah PT. Cipta Lamtoro Gung Persada. Untuk penggarapan lebih Ianjut upaya penyelenggaraan siaran televisi pendidikan, PT. Cipta Lamtoro Gung Persada membentuk anak perusahaan yang bernama PT. Cipta Televisi Pendidikan Indonesia (PT. CTPI). Sampai dengan tahun 1980-an, tidak ada stasiun televisi swasta yang diberi ijin oleh pemerintah untuk menyelenggarakan siaran televisi secara nasional. Hanya stasiun TVRI satu-satunya stasiun televisi yang mempunyai jaringan penyiaran program secara nasional.

Perjanjian kerjasama yang disepakati antara Depdiknas dengan PT. CTPI berlangsung selama 15 tahun. Sebagai tindak lanjut dari perjanjian kerjasama, berbagai kegiatan persiapan telah dilakukan, baik yang berupa penyiapan program-program pendidikan/ pembelajaran yang siap untuk ditayangkan (tugas dan tanggung jawab Pustekkom-Depdiknas) maupun penyiapan peralatan yang dibutuhkan untuk pendirian satu stasiun pemancar siaran televisi (tugas dan tanggung jawab PT Cipta Lamtoro Gung Persada). Pada tahun 1991, berdirilah secara resmi sebuah stasiun televisi swasta yang baru setelah RCTI dan SCTV yaitu yang bernama Stasiun Televisi Pendidikan Indonesia (Stasiun TPI). Stasiun TPI merupakan stasiun televisi swasta pertama yang mendapatkan ijin dari pemerintah untuk menyelenggarakan siaran televisi yang berskala nasional.

Beberapa butir kegiatan yang dirumuskan di dalam perjanjian kerjasama yang disepakati adalah bahwa Departemen Pendidikan Nasional melalui Pustekkom bertanggungjawab di bidang (1) pengembangan program siaran televisi pendidikan/pembelajaran yang siap tayang, (2) pengelolaan pemanfaatan program di tingkat sasaran (sekolah), (3) pemantauan dan pembinaan dalam pemanfaatan program siaran televisi. Sedangkan PT. CTPI bertanggungjawab (1) menyiarkan program pendidikan/ pembelajaran yang diproduksi Pustekkom dan (2) mengalokasikan waktu $16,6 \%$ dari keseluruhan waktu siaran untuk pendidikan sekolah dan $16,6 \%$ lainnya untuk program siaran pendidikan luar sekolah.

Program yang dirancang dan dikembangkan oleh PustekkomDepdiknas dan ditayangkan melalui stasiun TPI adalah program siaran televisi pendidikan sekolah (STVPS). Program STVPS mencakup materi pelajaran untuk peserta didik SD, SMP, dan Sekolah Menengah. Setelah mengudara sekitar 23 tahun, program STVPS sudah mulai banyak diketahui masyarakat pada umumnya dan masyarakat kependidikan pada khususnya. Untuk menstimulasi daerah dan sekolah dalam pemanfaatan program STVPS, Departemen Pendidikan Nasional melalui Pustekkom mendistribusikan peralatan/fasilitas pemanfaatan siaran televisi yang berupa pesawat televisi, pembangkit listrik tenaga surya (PLTS), video cassette recorder (VCR) dalam jumlah yang terbatas ke seluruh Indonesia.

Kerjasama Depdiknas dengan PT. CTPI ternyata tidak dapat berlangsung lama sebagaimana yang telah disepakati di dalam perjanjian kerjasama. Sekalipun kerjasama dengan pihak swasta ini terpaksa berhenti, namun gagasan Depdiknas melalui Pustekkom untuk dapat mengelola sendiri penyelenggaraan siaran televisi pendidikan tidak pernah berhenti.

Beberapa tahun kemudian, perjuangan untuk menyelenggarakan sendiri siaran televisi pendidikan akhirnya menuai hasil 
yaitu dengan dicanangkannya penyelenggaraan siaran televisi edukasi (TVE) pada tanggal 2 Oktober 2004 oleh Prof. Dr. Bambang Sudibyo, MBA selaku Menteri Pendidikan Nasional.

\section{Pertimbangan Pemanfaatan} Siaran Televisi untuk Pendidikan/ Pembelajaran

Siaran TVE tidak menggunakan jaringan teresterial sebagaimana stasiun-stasiun pemancar televisi yang ada tetapi melalui satelit Telkom-1. Oleh karena itu, siaran TVE tidak dapat ditangkap masyarakat luas melalui pesawat televisi yang hanya dilengkapi dengan antena biasa. Untuk dapat mengikuti siaran TVE, diperlukan adanya antena parabola yang diarahkan pada posisi satelit Telkom-1. Mengingat hanya masyarakat tertentu (terbatas) yang mempunyai akses terhadap pengadaan antenna parabola, Pustekkom menjalin kerjasama dengan berbagai stasiun televisi lokal yang ada di daerah. Dengan kerjasama dengan stasiun-stasiun televisi lokal ini, maka masyarakat luas yang di wilayahnya ada stasiun televisi lokal tidak perlu lagi bersusah payah mengadakan antenna parabola untuk memanfaatkan siaran TVE.

\section{a. Keterbatasan Tenaga Guru}

Mengingat keberadaan sekolah terutama Sekolah Dasar (SD) di daerah perdesaan, salah satu kesulitan atau hambatan yang dihadapi adalah ketersediaan guru. Tidak mengherankan apabila ada SD yang hanya dikelola oleh 1-3 orang guru. Sekalipun jumlah guru yang ada terbatas, namun anak-anak tetap dapat mengikuti kegiatan pembelajaran. Baik Kepala Sekolah maupun guru sama-sama berkomitmen untuk tetap menyelenggarakan kegiatan pembelajaran dengan strategi tertentu. Model Sekolah Dasar yang dikelola oleh jumlah guru yang terbatas seperti ini disebut dengan SD Kecil.
SD Kecil merupakan model pendidikan SD yang dikelola sedemikian rupa sehingga memungkinkan anak-anak SD pada semua kelas tetap dapat belajar. Seorang guru bertanggungjawab untuk membelajarkan anak-anak SD setidak-tidaknya yang berada dalam 2 rombongan belajar. Seandainya jumlah peserta didik dalam satu rombongan belajar tidak banyak, maka peserta didik dari 2 rombongan belajar dapat digabungkan di dalam satu ruang kelas.

Manakala jumlah peserta didik pada masing-masing rombongan belajar cukup banyak sehingga tidak memungkinkan menggabungkan mereka ke dalam satu ruang kelas, maka seorang guru haruslah mempunyai akses yang mudah untuk masuk ke dalam masing-masing ruang kelas. Artinya, ada pintu penghubung antara kedua ruang kelas sehingga guru mempunyai ruang gerak yang lebih dinamis untuk melayani kegiatan pembelajaran bagi peserta didik yang terdiri dari kedua rombongan belajar. Guru yang bertugas di SD Kecil mendapatkan pembekalan dan bimbingan khusus sehingga mereka tetap mempunyai semangat yang tinggi untuk melaksanakan panggilan tugas profesionalnya.

Dengan adanya sumber belajar lain di luar guru, terutama yang berupa media pembelajaran radio/audio dan televisi/video, maka peserta didik akan tetap dapat belajar. Ketersediaan sumber belajar lain yang dapat diakses oleh guru untuk kepentingan belajar peserta didik akan sangat membantu guru yang jumlahnya terbatas ini untuk mengelola kegiatan pembelajaran dengan sebaik-baiknya. Apabila media pembelajaran radio/audio dan televisi/video ini dirancang dengan baik, maka akan dapat menciptakan kegiatan pembelajaran yang lebih menarik sehingga peserta didik lebih 
termotivasi dalam kegiatan belajarnya.

b. Keterbatasan Sumber Belajar

Pada pendidikan formal persekolahan pun, keterbatasan sumber belajar yang dapat diakses, baik oleh guru maupun peserta didik, menjadi salah satu kendala untuk meningkatkan prestasi belajar peserta didik. Sumber belajar yang pada umumnya dapat dijumpai di lembaga pendidikan formal persekolahan masih terbatas pada bahan-bahan tercetak, seperti: buku teks, buku paket, atau bahan-bahan cetakan lainnya. Di sebagian sekolah, berbagai sumber belajar telah tersedia dan dimanfaatkan dalam kegiatan pembelajaran, seperti: Overhead Projector (OHP), kaset audio/CD, kaset video/VCD, internet.

Baik bagi sekolah-sekolah yang memang telah dilengkapi dengan berbagai sumber belajar maupun sekolah-sekolah yang mengalami kesulitan untuk mendapatkan sumber belajar, siaran televisi edukasi merupakan salah satu sumber belajar yang mendatangi peserta didik di sekolah dan di rumah. Di sekolah, program siaran TVE dapat dimanfaatkan peserta didik di bawah bimbingan guru, baik secara langsung mengikuti program siaran maupun secara tidak langsung melalui rekaman program siaran yang sudah dipersiapkan.

Siaran TVE dapat menjadi salah satu sumber belajar yang mendatangi peserta didik di sekolah pada jam-jam pelajaran kosong, baik secara individual maupun dalam kelompok kecil. Bagi peserta didik yang mempunyai antenna parabola di rumah atau di lingkungan tempat tinggalnya, mereka dapat memanfaatkan siaran TVE baik secara individual maupun dalam kelompok kecil. Di tempat yang sama, peserta didik juga dapat memanfaatkan siaran TVE dalam bentuk rekaman (VCD), baik secara perseorangan maupun kelompok kecil manakala mereka mempunyai fasilitas pemanfaatannya.

\section{c. Ketersediaan Pesawat Televisi di Masyarakat}

Secara umum, masyarakat tidak lagi mengalami kesulitan untuk memiliki pesawat televisi karena harganya yang semakin relatif terjangkau. Sekalipun belum semua keluarga mempunyai pesawat televisi, namun tidaklah sulit untuk menjumpai anggota masyarakat di komunitas tertentu yang memiliki pesawat televisi. Oleh karena itu, ketersediaan pesawat televisi di masyarakat dapat menjadi faktor penunjang bagi keterlaksanaan pemanfaatan siaran televisi untuk kepentingan pembelajaran.

Seandainya, pemanfaatan siaran televisi tidak dimungkinkan dilakukan peserta didik secara perseorangan, maka peserta didik dapat memanfaatkan siaran TVE secara kelompok di tempat yang fasilitas pemanfaatan siaran televisinya tersedia.

\section{d. Ketersediaan Stasiun Pemancar} Televisi di Daerah

Dewasa ini, semakin banyak daerah yang mendirikan stasiun pemancar televisi lokal. Di samping itu, ada juga perusahaan yang mendirikan stasiun televisi kabel yang memungkinkan masyarakat yang berminat dan mampu untuk berlangganan. Memperhatikan potensi keberadaan dari stasiun televisi lokal ini yang memungkinkan masyarakat luas dapat memanfaatkan siaran TVE, maka Pustekkom-Depdiknas telah menjalin kerjasama dengan sebagian stasiun televisi lokal.

Melalui kerjasama Pustekkom dengan para pengelola stasiun TV lokal, maka stasiun-stasiun televisi lokal menangkap siaran TVE dari satelit Telkom-1 dan kemudian 
menyiarkannya sehingga masyarakat yang berada di radius cakupan penyiarannya dapat memanfaatkan siaran TVE melalui pesawat televisi biasa. Sejauh ini, telah tercatat sekitar 109 stasiun TV lokal yang telah berperanserta dalam kerjasama untuk penyiaran program siaran TVE.

e. Ketersediaan Lembaga Produksi Program Media Televisi

Lembaga yang berkiprah di bidang pengembangan program siaran televisi (production house atau $\mathrm{PH}$ ) dari waktu ke waktu semakin bertambah jumlahnya, tidak hanya di Jakarta tetapi juga di daerah-daerah. Secara khusus, di lingkungan Departemen Pendidikan Nasional, ada institusi yang memang bertugas di bidang perancangan dan pengembangan program media siaran televisi, Pusat Teknologi Informasi dan Komunikasi Pendidikan (Pustekkom).

Pustekkom juga telah menyelenggarakan pelatihan mengenai pengembangan program siaran televisi, baik secara nasional maupun di propinsi-propinsi. Pelatihan yang dilakukan Pustekkom tidak hanya bagi para guru dan tenaga edukatif perguruan tinggi tetapi juga para tenaga yang bekerja di Unit Pelaksana Teknis Daerah Balai Teknologi Informasi dan Komunikasi (UPTD Balai Tekkom) di berbagai propinsi. Di samping itu, semakin bertambah jumlah lembaga swasta dan perorangan di berbagai daerah yang berkiprah di bidang pengembangan program media televisi. Dengan keberadaan berbagai lembaga (UPTD Balai Teknologi Informasi dan Komunikasi di berbagai propinsi dan lembaga swasta) dan perorangan ini, maka keberadaan stasiun-stasiun televisi yang jumlahnya juga terus meningkat, tidak akan terkendala dalam pengadaan program media siaran televisi untuk kepentingan pendidikan/pembelajaran.

\section{Pengalaman Menyelenggarakan Siaran Televisi Edukasi}

\section{a. Pencanangan Siaran Televisi Edukasi}

Televisi Edukasi (TVE) adalah sebuah stasiun televisi di Indonesia yang secara khusus ditujukan untuk menyebarluaskan informasi di bidang pendidikan dan berfungsi sebagai media pembelajaran masyarakat. Motto siaran TVE adalah "Santun dan Mencerdaskan". Stasiun televisi ini diresmikan oleh Menteri Pendidikan Abdul Malik Fadjar tanggal 12 Oktober 2004 dan berada di lingkungan Pustekkom-Depdiknas, Jl. R. E. Martadinata, Ciputat, Tangerang Selatan, propinsi Banten.

Siaran Televisi Edukasi (TVE) merupakan suatu upaya pemanfaatan siaran televisi melalui satelit Telkom-1. Siaran TVE adalah siaran yang sepenuhnya didedikasikan bagi kepentingan pendidikan/pembelajaran. Sebagai konsekuensinya, siaran TVE hanya dapat dimanfaatkan apabila pesawat televisi yang digunakan dilengkapi dengan antenna parabola. Hal ini berarti bahwa pada prinsipnya, siaran TVE dapat ditangkap di mana saja asalkan pesawat televisi yang digunakan dilengkapi dengan antenna parabola. Antena parabola yang digunakan haruslah diarahkan ke satelit Telkom-1 dengan frekuensi: $3785 \mathrm{MHz}$; symbol rate: $4000 \mathrm{Ms}$; polarisasi: horisontal; LO/LNB: 05150; Video PID: 0308; Audio PID: 0526; dan PCR PID: 08190 (Hardjito, 2007).

Pada tahap awal operasionalisasi stasiun TVE, siarannya hanya berlangsung selama 2 (dua) jam setiap hari dengan perincian 1 (satu) jam siaran di pagi hari dan 1 (satu) jam siaran ulang pada sore harinya. Jumlah jam siaran TVE terus ditingkatkan dari tahun ke tahun. Yang menjadi sasaran utama siaran TVE adalah peserta didik Sekolah Menengah Pertama (SMP) dan yang 
sederajat. Materi pelajaran yang dikembangkan dan ditayangkan adalah mata pelajaran yang ditetapkan oleh pemerintah untuk diuji secara nasional. Untuk mengetahui lebih lanjut mengenai siaran TVE, website yang dapat dikunjungi adalah: http://www.tvedukasi.or.id

\section{b. Perkembangan Siaran Televisi Edukasi}

Jumlah jam siaran TVE dari waktu ke waktu terus bertambah secara bertahap seiring dengan kesiapan sumber daya manusianya. Pada tahun 2009, stasiun TVE mengudara selama 24 jam. Materi pendidikan yang ditayangkan juga semakin bertambah, tidak lagi hanya materi pembelajaran yang ditujukan bagi peserta didik pendidikan formal (pendidkan dasar, pendidikan menengah, dan pendidikan tinggi), pendidikan non-formal, materi pembelajaran untuk pendidikan informal, tetapi juga mencakup penyangan informasi tentang pembangunan pendidikan.

Mengingat peranan guru yang sangat strategis dalam pengembangan kualitas sumber daya manusia Indonesia, maka PustekkomDepdiknas merancang dan mengembangkan program siaran yang ditujukan untuk pengembangan potensi guru dalam melaksanakan tugas profesionalnya, baik yang mencakup peningkatan kompetensi, kualifikasi, dan untuk kepentingan sertifikasi. Program yang didedikasikan secara khusus untuk para guru ini dapat diikuti melalui saluran 2 (channel 2) stasiun TVE.

Pada tahap-tahap awal siaran, program siaran TVE saluran 2 dikembangkan secara interaktif. Para guru yang mengikuti program siaran TVE saluran 2 ini dapat menggunakan saluran telepon untuk memberikan pendapat, pertanyaan, atau berbagi pengalaman (sharing experiences). Pemanfaatan siaran
TVE saluran 2 dapat dilakukan oleh guru, baik secara klasikal di Lembaga Penjaminan Mutu Pendidikan (LPMP) dan di Unit Pelaksana Belajar Jarak Jauh-Universitas Terbuka (UPBJJUT), secara kelompok di Kelompok Kerja Guru (KKG), Musyawarah Guru Mata Pelajaran (MGMP), Musyawarah Kerja Kepala Sekolah (MKKS), maupun secara individual di rumah atau di sekolah (PustekkomDepdiknas, 2009).

Dari sejak awal, berdasarkan berbagai pertimbangan, siaran TVE memang dirancang untuk menggunakan fasilitas satelit. Hal ini berarti bahwa seluruh program yang dirancang dan dikembangkan oleh Pustekkom-Depdiknas di-uplink ke satelit Telkom-1 dari studio stasiun TVE Pustekkom-Depdiknas. Pemanfaatan siaran TVE oleh lembaga-lembaga pendidikan formal dan non-formal serta masyarakat luas harus menggunakan antenna parabola yang diarahkan pada posisi satelit Telkom-1.

Perkembangan yang terjadi dewasa ini adalah bahwa siaran TVE telah dapat dimanfaatkan melalui fasilitas internet karena PustekkomDepdiknas telah menggunakan Internet Protocol for Television (IPTV) dalam penyelenggaraan siaran TVE. Dalam kaitan ini, TVE streaming (ujicoba) dapat diakses melalui http:/ /tve.depdiknas.go.id/index.php/tvonline.html atau http:// www.mitratve.com. Persyaratan untuk menikmati TVE melalui intra/ internet (TVE streaming) adalah bahwa pengguna memiliki saluran internet atau intranet Jardiknas, komputer yang digunakan memiliki internet explorer dengan windows media player plug in (active plug in enabled), atau firefox dengan VLC plug in, atau quicktime, real player, dan bandwith minimal 256 kbps (Pustekkom-Depdiknas, 2009). 
Selain itu, dengan menggunakan fasilitas "Set Top Box" (STB) yang berfungsi sebagai pengubah sinyal digital menjadi analog, maka masyarakat dapat memanfaatkan siaran TVE yang masih menggunakan sinyal analog. Keuntungan lain dari penggunaan "Set Top Box" adalah kenyaman pemirsa menonton siaran televisi dengan kualitas tayangan yang jernih. Siaran TV digital yang menggunakan jaringan teresterial akan diterapkan secara bertahap dimulai dari wilayah (1) Jabodetabek pada tahun 2009, (2) Jawa-Bali-Makassar-Medan pada tahun 2012, dan (3) secara menyeluruh siaran TV digital akan dinikmati pada tahun 2018 (Pustekkom-Depdiknas, 2009).

\section{c. Ragam Program yang Ditayangkan stasiun TVE}

Sejak tahun 2004, stasiun TVE mulai mengadakan kuis KIHAJAR Award yang merupakan akronim dari "Kita Harus Belajar". Kuis ini bertujuan untuk mencari peserta didik SMP yang berprestasi. Peserta didik yang berprestasi ini adalah juga yang aktif dan teratur mengikuti tayangan TVE dan memberikan respons terhadap materi kuis yang disampaikan selama siaran.

Seleksi peserta didik yang mengikuti siaran TVE dilakukan mulai pada tingkat kabupaten/ kota. Mereka yang berhasil melewati seleksi tingkat kabupaten/kota diundang untuk mengikuti seleksi tingkat propinsi. Demikian juga dengan peserta didik yang berhasil melewati seleksi tingkat propinsi diundang untuk mengikuti seleksi tingkat nasional di Jakarta. Peserta didik yang berhasil memenangkan kuis KIHAJAR Award pada tingkat nasional diberikan beasiswa untuk menyelesaikan pendidikan sampai dengan Strata-1 (S-1).
Komposisi program pendidikan/ pembelajaran yang ditayangkan melalui siaran TVE adalah 30\% untuk pendidikan formal, $30 \%$ untuk pendidikan non-formal, $20 \%$ untuk pendidikan informal, dan $20 \%$ untuk kepentingan informasi pendidikan (Hardjito, 2007). Yang menjadi sasaran dari program siaran TVE adalah (1) para peserta didik pada semua jalur, jenjang, dan jenis pendidikan, (2) para praktisi pendidikan, dan (3) masyarakat luas.

\section{d. Pengelolaan Pemanfaatan Siaran TVE}

Sebagaimana yang telah diuraikan sebelumnya bahwa siaran TVE menggunakan fasilitas satelit Telkom1 dalam penyelenggaraan siarannya. Dipahami benar bahwa hanya masyarakat yang mempunyai fasilitas antenna parabola saja yang dapat menikmati siaran TVE. Agar masyarakat luas dimungkinkan untuk dapat menikmati siaran TVE, Depdiknas melalui Pustekkom menjalin kerjasama dengan stasiun TVRI, berbagai stasiun TV lokal yang tersebar di berbagai daerah, dan stasiun TV Kabel.

Mengingat stasiun TVRI Jakarta telah berpengalaman bekerjasama dengan Pustekkom-Depdiknas dalam penyangan program-program siaran televisi pendidikan/pembelajaran dan jaringan penyiaran yang dimiliki TVRI secara nasional, maka PustekkomDepdiknas menjalin kerjasama penyiaran program TVE pada tahun 2006. Stasiun TVRI menyiarkan program TVE selama 4 (empat) jam setiap hari Senin sampai dengan Kamis. Perinciannya adalah dimulai pada pukul 07.00-09.00 WIB pagi hari dan disiarkan ulang pada pukul 14.00-16.00 WIB di sore harinya (Hardjito, 2007). Materi pelajaran yang ditayangkan masih tetap fokus pada materi pelajaran untuk peserta didik SMP. 
Selain bekerjasama dengan stasiun TVRI Jakarta, Pustekkom-Depdiknas juga menjalin kerjasama dengan berbagai stasiun TV lokal di seluruh Indonesia dan stasiun TV Kabel dalam menerus-siarkan program TVE. Melalui jalinan kerjasama Pustekkom-Depdiknas dengan stasiun TVRI Jakarta, stasiun TV lokal, dan stasiun TV Kabel, maka diharapkan akan semakin memudahkan peserta didik, guru, dan masyarakat pada umumnya memanfaatkan siaran TVE secara langsung dengan perangkat televisi biasa. Kondisi yang demikian ini akan dapat meningkatkan jumlah masyarakat pada umumnya dan masyarakat kependidikan pada khususnya yang dapat memanfaatkan program siaran TVE.

Upaya lain untuk meningkatkan jumlah sekolah yang dapat memanfaatkan siaran TVE, maka Pustekkom telah mengucurkan dana dalam bentuk block-grant ke semua Dinas Pendidikan tingkat Propinsi dalam pengadaan pesawat televisi, antena parabola, DVD player, pembangkit tenaga listrik (genset). Pengadaan peralatan pemanfaatan program siaran yang diadakan melalui Dinas Pendidikan tingkat Propinsi, didistribusikan ke sekolahsekolah (SD/MI, SMP/MTs, dan SMA/ SMK/MA). Pengucuran dana ini diharapkan dapat menjadi stimulans, baik bagi Pemerintah Daerah (Pemda), sekolah-sekolah, maupun lembaga-lembaga sosial masyarakat yang peduli dengan masalahmasalah pendidikan.

Selanjutnya, beberapa pola pemanfaatan siaran TVE yang dapat dipertimbangkan untuk diterapkan, baik di sekolah di bawah bimbingan guru atau atas inisiatif para peserta didik sendiri, maupun di luar sekolah oleh peserta didik secara individual atau kelompok. Secara garis besar, ada 3 pola pemanfaatan siaran TVE yang ditawarkan PustekkomDepdiknas (Warsihna, dkk., 2007), yaitu:

1) Pola pemanfaatan yang bersifat klasikal. Siaran TVE dimanfaatkan secara terpadu dalam proses belajar-mengajar di bawah bimbingan guru untuk peserta didik yang berada di dalam satu kelas. Setelah pemanfaatan siaran TVE selesai, guru memberikan kegiatan tindak lanjut yang harus dilaksanakan peserta didik. Materi tindak lanjut dapat diambil guru dari Lembar Kerja Siswa (LKS).

2) Pola pemanfaatan dalam kelompok kecil. Siaran TVE yang dimanfaatkan oleh peserta didik dalam jumlah 5-10 orang, baik di sekolah (pada jam-jam pelajaran kosong/bebas) maupun di luar sekolah. Peserta didik memanfaatkan siaran TVE setelah mendapatkan bimbingan dan arahan dari guru mata pelajaran.

3) Pola pemanfaatan yang bersifat individual. Peserta didik secara perseorangan dapat memanfaatkan siaran TVE, baik di sekolah maupun di tempat lain. Dalam hal ini, siaran TVE berfungsi sebagai materi pengayaan bagi peserta didik. Oleh karena itu, peranan guru sangat penting dalam memotivasi peserta didiknya sehingga tergugah untuk memanfaatkan siaran TVE di waktu-waktu luangnya.

Selain untuk kepentingan peserta didik, siaran TVE juga ditujukan untuk kepentingan peningkatan potensi guru melalui saluran 2 siaran TVE, baik yang berkaitan dengan kompetensi, kualifikasi, maupun sertifikasi. Program siaran TVE untuk guru dimulai pada tahun 2009 dengan jadwal siaran pada hari Senin sampai dengan Sabtu, dimulai pada pukul 12.00-20.00 WIB; sedangkan pada hari Minggu dan libur, siaran TVE 
saluran 2 dilaksanakan pada pukul 12.00-17.00 WIB (PustekkomDepdiknas, 2009).

Seiring dengan kemajuan teknologi informasi dan komunikasi, berbagai konten pendidikan dan pembelajaran melalui siaran TVE dapat di-downlink dari satelit Telkom-1. Kepala Sekolah, guru, atau peserta didik dapat mengetahui jadwal siaran TVE melalui akses ke website Pustekkom. Kemudahan ini membantu guru dan peserta didik mempersiapkan diri untuk memanfaatkan siaran TVE. Tidak hanya jadwal siaran TVE, tetapi berbagai konten yang pendidikan/ pembelajaran dapat diakses oleh guru dan peserta didik atau siapa saja untuk dimanfaatkan sesuai dengan kebutuhannya.

Bahkan untuk memotivasi atau menggugah para peserta didik memanfaatkan siaran TVE, Pustekkom menyelenggarakan kuis KiHajar (Kita Harus Belajar) bagi para peserta didik SMP. Pertanyaanpertanyaan kuis disampaikan pada saat siaran dan peserta didik dapat menjawabnya melalui fasilitas sambungan telepon bebas pulsa. Bagi peserta didik yang berhasil melalui seleksi dari tingkat kabupaten/ kota sampai ke tingkat nasional, diberikan beasiswa untuk meneruskan pendidikannya sampai ke perguruan tinggi (S-1).

\section{PENUTUP}

\section{Kesimpulan}

Gagasan Departemen Pendidikan Nasional melalui Pusat Teknologi Informasi dan Komunikasi Pendidikan (PustekkomDepdiknas) untuk menyelenggarakan siaran televisi pendidikan/ pembelajaran diawali dengan pengembangan programprogram pengembangan/pembinaan watak anak-anak usia Sekolah Dasar yang ditayangkan melalui stasiun Televisi Republik Indonesia (TVRI) Jakarta. Sekalipun menghadapi berbagai kendala dalam mewujudkan gagasan untuk menyelenggarakan satu stasiun siaran televisi yang secara khusus berkiprah di bidang pendidikan/pembelajaran, namun pada akhirnya pada tahun 2004, Menteri Pendidikan Nasional mencanangkan dimulainya operasionalisasi stasiun siaran TVE.

Siaran televisi pendidikan/pembelajaran, yang diselenggarakan oleh PustekkomDepdiknas yang kemudian lebih dikenal dengan nama siaran TVE, tidak hanya mencakup materi pendidikan formal, nonformal tetapi juga pendidikan informal dan informasi pendidikan. Siaran TVE tidak hanya ditujukan bagi kepentingan peserta didik pendidikan formal (persekolahan) tetapi juga bagi kepentingan pengembangan potensi diri para guru, baik yang berkaitan dengan peningkatan kompetensi, kualifikasi, maupun untuk kepentingan sertifikasi guru.

\section{Saran-saran}

Memperhatikan berbagai kendala dalam memperoleh sumber-sumber belajar, terutama bagi peserta didik yang berada di daerah perdesaan, terpencil, sulit geografisnya, dan perbatasan, maka siaran TVE merupakan alternatif sumber belajar yang dapat dengan mudah diakses. Oleh karena itu, perlu dipertimbangkan berbagai upaya yang dapat memfasilitasi sekolah dan peserta didik yang berada di daerah-daerah perdesaan, terpencil, sulit geografisnya, perbatasan sehingga memungkinkan mereka memanfaatkan siaran TVE secara teratur.

\section{DAFTAR PUSTAKA}

Anwas, Oos M. (2009). Membangun Media Massa yang Mendidik Masyarakat. Artikel dalam Subijanto (2009). Jurnal Pendidikan dan Kebudayaan, Vol. 15 No.: 1 Januari 2009. Jakarta: Badan Penelitian dan Pengembangan-Departemen Pendidikan Nasional.

Fowles, Barbara R. 1978. "A Child and His Television Set: What is the Nature of 
Relationship". Artikel dalam buku Chester M. Pierce. Television and Education. Beverly Hills/London: A Sage Contemporary Sosial Science Issue.

Hardjito. (2007). Pedoman Pemanfaatan Siaran Televisi Edukasi, Santun dan Mencerdaskan. Jakarta: Pusat Teknologi Informasi dan Komunikasi PendidikanDepartemen Pendidikan Nasional.

Pusat Teknologi Informasi dan Komunikasi Pendidikan-Departemen Pendidikan Nasional. (2009). Petunjuk Kegiatan: Penjajagan TV Lokal/TV Kabel, Pembinaan Sekolah Binaan TVE, dan Sosialisasi TVE Channel 2. Jakarta: Pusat Teknologi Informasi dan Komunikasi PendidikanDepartemen Pendidikan Nasional.
Siahaan, Sudirman; Waldopo; dan M. Oos Iskandar. (2006). Televisi Pendidikan di Era Global. Jakarta: Pusat Teknologi Informasi dan Komunikasi Pendidikan-Departemen Pendidikan Nasional.

Warsihna, Jaka, dkk. (2007). Pedoman Pemanfaatan Siaran Televisi Edukasi (TVE). Jakarta: Pusat Teknologi Informasi dan Komunikasi Pendidikan-Departemen Pendidikan Nasional

Wirjomartono, Sri Hardjoko. (1994). "Pendayagunaan Radiko dan Televisi dalam Pendidikan". Makalah yang disajikan dalam Seminar Lokakarya Nasional Teknologi Pendidikan tentang Media Massa Elektronik dan Pendidikan Sumber Daya Manusia, 1-3 Pebruari 1994 di Jakarta. Jakarta: IPTPI, CTPI, Pustekkom. 